\title{
Soil drainage as an active agent of recent soil evolution: a
}

\section{review*}

\author{
David Montagne ${ }^{\mathrm{a}, \mathrm{b}}$, Sophie Cornu ${ }^{\mathrm{a}}$, Lydie Le Forestier ${ }^{\mathrm{c}}$, Isabelle Cousin ${ }^{\mathrm{a}}$
}

âNRA-UR 0272, Unité de Science du Sol, centre de recherche d’Orléans, 2163 avenue de la Pomme de Pin, BP 20619 Ardon, F-45166 Olivet Cedex (France)

${ }^{\mathrm{b} U M R}$ INRA/AgroParisTech Environnement et Grandes Cultures (EGC), BP 01, F-78850

Thiverval-Grignon (France)

'ISTO (UMR 6113), Polytech’Orléans, 8 rue Léonard de Vinci, F-45072 Orléans cedex 2 (France)

E-mail : david.montagne@agroparistech.fr

* Project supported by the Région Centre, France

\begin{abstract}
While research on pedogenesis mainly focuses on the long-term soil formation and most often neglects recent soil evolution in response to human practices or climate changes, this article reviews the impact of artificial subsurface drainage on soil evolution. Artificial drainage is considered as an example of the impact of recent changes in water fluxes on soil evolution over time scales of decades to a century. Results from various classical studies on artificial drainage including hydrological and environmental studies are reviewed and collated with rare studies dealing explicitly with soil morphology changes, in response to artificial drainage. We deduce that soil should react to the perturbations associated with subsurface drainage over time scales that do not exceed a few decades. Subsurface drainage decreases the intensity of erosion and must i) increase the intensity of the lixiviation and eluviation processes, ii) affect iron and manganese
\end{abstract}


dynamics, and iii) induce heterogeneities in soil evolution at the ten meter scale. Such recent soil evolutions can no longer be neglected as they are mostly irreversible and will probably have unknown, but expectable, feedbacks on crucial soil functions such as the sequestration of soil organic matter or the water available capacity.

Keywords: cultivation, human-induced soil evolution, pedogenesis, soil processes, subsurface drainage.

Soil evolves permanently under the impact of fluxes of matter and energy (Chadwick and Chorover, 2001). These fluxes change through time according to the main pedological factors defined by Jenny (1941, 1961), namely topography, climate, and biota, including man, who was early recognized as a factor affecting soil evolution through his impact on fluxes (Yaalon and Yaron, 1966). Recent changes in these fluxes, in response to either human practices or global climate change, have probably resulted in recent soil evolutions. Such recent soil evolutions over time scales of a few decades are, however, most often neglected by comparison to the long-term soil formation on millennial to multi-millennial time scales and are not very well known until now.

Water fluxes are of particular concern as water is the weathering reactive agent as well as the transporting phase. Thus, changes in water fluxes affect chemical weathering and transport of solutes and particles through soils (Chadwick and Chorover, 2001; Lin et al., 2005). Changes in water fluxes due to practices such as irrigation or drainage must induce recent soil evolutions. Irrigation mainly increases the amount of water flowing through soils. Artificial subsurface drainage, designed to remove excess water from soils, not only reduces the residence time of water in soils and increases soil aeration inducing changes in its redox status, but also increases the amount of infiltrating water and induces changes in the water pathways by respectively reducing the runoff (Bengtson et al., 1995; Grazhdani et al., 1996) and intercepting water fluxes at regular 
intervals. Thus, artificial drainage seems to affect water fluxes in soils to a greater extent than irrigation. The authors consequently decided to review the impact of changes in the water fluxes induced by drainage on the recent soil evolutions.

Many researches on artificial drainage have focused on the hydraulic behavior of drained plots (Bottcher et al., 1980; Lesaffre and Zimmer, 1987a, b; Abbaspour et al., 2001). During the last decade, more attention has been paid to the quality of drainage water, which has a great influence on stream water quality (Penven and Muxart, 1995; Kronvang et al., 1997). Most of these studies have focused on nitrogen, phosphorus, and pesticides losses through drainage water (Belamie and Vollat, 1986; Grant et al., 1996; Simard et al., 2000; Villholth et al., 2000; Zehe and Flühler, 2001; Petersen et al., 2002; Novak et al., 2003). As phosphorus and pesticides are often bound to particulate matter, sediment losses have also been monitored (Schwab et al., 1980; Bottcher et al., 1981; Øygarden et al., 1997; Petersen et al., 2002; Novak et al., 2003). Conversely, very few studies have been performed on the impact of drainage on soil evolution except those, mostly qualitative, of Kapilevich et al. (1991) and Hayes et al. (2000). This is surprising, however, as about 190 million hectares, that is, more than $10 \%$ of the world's arable and permanently cropped area, are drained and up to about $80 \%$ of this area is in countries, such as, Egypt, Japan or the United Kingdom. In addition, drained soils are often part of the most productive soils, for example, soils in Finland (Uusitalo et al., 2001). This review aims at reinterpreting the available data from studies on the hydraulic behaviour of drained soils and with environmental purposes, in terms of soil evolution under the impact of artificial subsurface drainage.

Agricultural land drainage usually consists of surface or subsurface systems, or a combination of both. The scope of this review is deliberately reduced to subsurface systems.

\section{QUALITATIVE EVIDENCES OF THE IMPACT OF SOIL DRAINAGE ON SOIL}

\section{EVOLUTION}


To the author's knowledge, only two studies have dealt with the evolution of pedological properties (colours, texture, and Fe and Mn distribution) due to soil artificial drainage (Kapilevich et al., 1991; Hayes et al., 2000). Kapilevich et al. (1991) described the soil evolution of a catena drained for 18 years, consisting in the succession, along a slope of three clay-differentiated soils, exhibiting an increasing degree of waterlogging. Soil drainage was found i) to enhance the eluviation processes a shown by the appearance of abundant plasma-depleted patches in the eluvial horizon, concurrently, with thin argillaceous cutans on the wall of cracks in the illuvial horizon, and ii) to modify the redox processes by favoring the precipitation of $\mathrm{Fe}$ oxides, as the waterlogging period decreased in duration and intensity. Hayes et al. (2000) stated that the impact of soil drainage on redox processes was the function of the distance to the ditch in case of soil drainage by open ditches. They indeed demonstrated that the proportion of the surface of the soil profile occupied by Fe and Mn accumulations increased as the distance to the ditch decreased.

\section{IMPACT OF SUBSURFACE DRAINAGE ON SOIL FUNCTIONING}

The impact of subsurface drainage on soil functioning is first reviewed in terms of water fluxes in soils and then in terms of water quality. The authors first focus on studies dealing with i) changes in porosity and soil structure, and then with ii) the hydrologic behavior of drained plots. Subsequently, the impact of subsurface drainage in terms of transport of either dissolved or particulate matter is reviewed considering successively i) the amount and the dynamic of the matter transported, ii) the nature of the transported matter, and iii) its origin.

\section{Impact of subsurface drainage on water fluxes}

Several studies compared surface and drainage flows in drained plots with surface runoff in undrained plots (Mériaux et al., 1971; Skaggs et al., 1994; Bengtson et al., 1995; Grazhdani et al., 1996; Augeard et al., 2005). They agreed that drainage reduced runoff and conversely increased 
the amount of water infiltrating into soils. According to Skaggs et al. (1994) reviewing the impact of artificial drainage on hydrology in the United States of America, subsurface drainage reduced runoff by 34 to $55 \%$ in comparison with similar undrained soils. Due to the lack of evapotranspiration measurements, it was difficult to infer from these data the effects of drainage on the overall water balance. Nevertheless, as most of the drainflow occurred during winter when the vegetation was not active, the authors could suppose, in a first approximation, that the decrease by $34 \%$ to $55 \%$ of runoff corresponded to an equal increase of the amount of water flowing through soils. In addition, artificial drainage reduced the average annual duration and consequently the intensity of the waterlogged period, compared to similar undrained soils. However, if such changes mainly concern the surface soil horizons, a seasonal watertable still exists deeper in the subsoil, in most drained soils (Mériaux et al., 1971; Kapilevich et al., 1991; Husnjak et al., 2002).

Subsurface water pathways in drained soils determined by changes in porosity and soil structure

The installation of a subsurface drainage network induces large voids above the drain location due to reorganization of soil clods because of physical trenching, subsoiling, and mixing or backfilling of the drainage trench (Trouche, 1981; Øygarden et al., 1997). This human-induced porosity generally declines with time, notably in the case of a prolonged waterlogged period (Zaidel'man and Vashkova, 1989). However, Mercier (1998) observed that on thin sections, porosity remained due to drainage trenching 15 years after drainage installation in a Luvisol. The initial human-induced porosity can thus persist at least in favorable situations.

Moreover, better aeration conditions improve soil structuration due to wetting and drying cycles (Kapilevich et al., 1991) and biological activity. Indeed more earthworm burrows have been observed in drained soils than in similar undrained soils (Carter et al., 1982). They are mainly located above the drain (Urbanek and Dolezal, 1992; Shipitalo et al., 2004), most of them being directly connected to the drain (Urbanek and Dolezal, 1992; Øygarden et al., 1997; Stamm et al., 
2002; Shipitalo et al., 2004). As a result of the three processes (physical disturbance, pedological structuration by wetting and drying cycles, and biological activity), higher infiltration rates and lower bulk density are generally observed above the drain lines in comparison with the undisturbed soil at the mid-drain position (Table 1).

Gardner et al. (1994) measured an increase in porosity on 20 soil cores randomly sampled in the surface horizon of a drained and undrained plot after 1, 2, and 3 years of drainage. These results could however not be generalized as the drains were laid at only a $40 \mathrm{~cm}$ depth with a drain spacing of 2 meters, which was not a common configuration (Table II). Kapilevich et al. (1991) observed that the initial dense and massive structure of the undrained soil was progressively replaced by a microaggregate structure on the surface horizons and by a columnar structure on the illuvial horizons as a result of the improved aeration conditions at the mid-drain position, with a drain-spacing of 10 meters (Table II). After 10 to 18 years, depending on the initial soil hydromorphic status, a network of cracks with vertical cracks as wide as $0.5 \mathrm{~mm}$ was observed in the subsurface horizons. It thus suggested that changes in soil structure due to artificial drainage were not restricted to the immediate vicinity of the drain lines, but affected more or less the entire inter-drain space. However, the distance from the drain affected by the drainage remained largely unknown.

Subsurface water pathways in drained soils as determined in hydrological studies

The impact of soil drainage on water pathways in drained soils has been extensively studied notably from tracer experiments. Most of these experiments monitored the drainage water discharge and measured tracer content in the drain flow (Bengtsson et al., 1992; Kung et al., 2000a, b; Gish et al., 2004; Petersen et al., 2004). Few studies combined the monitoring of drainage water discharge with the analysis of the tracer content in the soil water or the direct 
observation in the solum in case of dye tracer experiments (Mériaux, 1973; Merot and Hamdi, 1991; Øygarden et al., 1997; Kohler et al., 2003; Shipitalo et al., 2004).

Two different situations are encountered depending on the location of the drain with respect to the impeding horizon (Fig. 1). Generally, the drains are located above the restrictive soil layer. In such cases, the water flows mostly vertically until it reaches the top of the water table. Then the streamlines converge laterally toward the drains from both above and below them (Fig. 1). In the second situation, the drains are placed in or below the restrictive soil layer, which is either a compacted plough layer (Trouche, 1981), a clay-rich horizon in a texturally-differenciated soil (Mériaux et al., 1971) or a clayey soil subjected to swelling processes (Cros and Jacquin, 1972; Merot and Hamdi, 1991; Turtola and Paajanen, 1995; Øygarden et al., 1997; Shipitalo et al., 2004) (Table II). In this case, numerous authors have proposed the following flow pattern: i) rainfall water infiltrates vertically into the soil until it reaches the impeding horizon; ii) the water flows mostly laterally according to the steepest slope orientation; iii) lateral water flows are then intercepted by preferential flowpaths and/or the disturbed soil volume, due to subsoiling or trenching at the vertical point of the buried drain line, and iv) the water reaches the drain line vertically and is finally evacuated from the soil (Fig. 1). If these two scenarios are efficient for describing water fluxes in contrasted types of drained soils, many soils are most probably somewhere in between these two situations. Anyway, in both cases, the drainage increases the lateral component of the water fluxes from the inter-drain space toward the drain lines. These fluxes are shallower, more concentrated, and finally probably faster in case of a restrictive layer above the drain lines than in case of a restrictive layer below the drain lines. In the following sections, this study will mainly focus on drained soils with a restrictive layer above the drain lines, as the authors consider that the impact of soil drainage will be more important given that the water fluxes are concentrated in a relatively small volume of the whole soil profile. 
Impact of drainage on the transport of dissolved and particulate matter

Although major soil element losses such as $\mathrm{Ca}, \mathrm{K}, \mathrm{Mg}$, and $\mathrm{Na}$ at the drainage outlet have already been evidenced (Schwab et al., 1980), they have been rarely monitored or quantified. The losses of Fe or Mn, notably in dissolved forms, have never been monitored to one's knowledge, although these elements could be dissolved and evacuated during the waterlogging period. Owing to lack of quantification, the impact of major element losses, due to artificial drainage, on evolution of the soil solid phase through chemical weathering is unpredictable, and the use of the water quality to identify the soil forming processes occurring in drained soils is impossible. The existing knowledge about the quantity, quality, and origin of the lost particles was summarized as follows. .

\section{Amounts and dynamic of particle losses at the drainage network outlet}

Numerous studies, dealing with environmental conservation, monitored particle losses at the drainage network outlet throughout the year or during particular rainfall events (Grant et al., 1996; Laubel et al., 1999; Ulen and Persson, 1999; Djodjic et al., 2000).

In different studies (Table III), particle losses ranged from negligible amounts, around $1 \mathrm{~kg}$ ha $^{-1}$ year $^{-1}$, to quantities exceeding $5000 \mathrm{~kg} \mathrm{ha}^{-1}$ year $^{-1}$ (Table III). In addition to this inter-plot variability, Schwab et al. (1980) monitered yearly particles losses ranging from less than $100 \mathrm{~kg}$ ha $^{-1}$ year $^{-1}$ to more than $5000 \mathrm{~kg} \mathrm{ha}^{-1}$ year $^{-1}$ on the same plot during a ten-year study.

The high inter-plot and temporal variability of particle losses seems to be related to i) the soil properties: particle losses exceeding $1000 \mathrm{~kg} \mathrm{ha}^{-1}$ year $^{-1}$ were only recorded in heavy clay soils (Tables II and III); ii) the design of the drainage network: the smaller the drain spacing, the higher the particle losses (Kladivlo et al., 1991); iii) the total drainflow: particle losses globally increase with drainflow, although this relationship suffers numerous exceptions as reported, for example, in Schwab et al. (1980); iv) agricultural practices such as soil tillage favored particle losses (Schwab et al., 1980; Øygarden et al., 1997; Simard et al., 2000; Koskiaho et al., 2002) ; and v) the 
antecedent soil moisture conditions : particle losses are generally higher on a dry soil than on a moist soil (Bottcher et al., 1980; Simard et al., 2000). Laubel et al. (1999) showed that loss rates were thus higher during the first autumn storm after the dry season than during winter storms. This seasonal trend was attributed to the gradual decrease of the easily available particle pool produced during the dry season due to both biological activity and soil drying (Grant et al., 1996; Kronvang et al., 1997; Laubel et al., 1999), but contradictory results are also reported (Petersen et al., 2004).

Despite high inter-plot and annual variability, all studies agreed that storm events contributed to an important part of the annual particle losses. As an example, Laubel et al. (1999), measuring soil losses at the drainage outlet at the storm flow event scale reported total soil losses ranging from about 1 to more than $10 \mathrm{~kg} \mathrm{ha}^{-1}$ year $^{-1}$ (Table III). Such losses were of a similar magnitude than annual losses measured on similar soils by Petersen et al. (2004) or Sogon et al. (1999). At the event scale, particles were mainly transported to the drain at the early beginning of drainflow events, the maximum concentrations in particles being often observed before the peak drainwater discharge (Grant et al., 1996; Kronvang et al., 1997; Penven et al., 1998; Laubel et al., 1999; Petersen et al., 2004). Subsequently, both the drainflow and its particulate matter (PM) concentrations rapidly declined with time. This very rapid increase in discharge and particle concentrations followed by a similar rapid decline was usually interpreted as a result of preferential flows through soil macroporosity (Kumar et al., 1997; Lenmartz et al., 1999; Kohler et al., 2003; Köhne and Gerke, 2005).

Importantly, soil losses at the drainage network outlet have been observed for soils of various textures ranging from sandy loam to clay (Bottcher et al., 1981; Turtola and Paajanen, 1995; Grant et al., 1996; Grazhdani et al., 1996; Koskiaho et al., 2002; Petersen et al., 2002); even for very flat lands with a mean slope of less than 1\% (Bottcher et al., 1981; Djodjic et al., 2000). Consequently, particle losses appear as a very common phenomenon that affects most drained soils. They are quantitavely often smaller than those due to erosion processes (Table III) but 
remain important source of sediments accounting for 10\% to 20\% (Kronvang et al., 1997) and even for 34\% to 65\% (Russel et al., 2001; Walling et al., 2002) of the sediments transported by the river of small agricultural drained catchments. Similarly, Foster et al. (2003) dating sediment cores observed a fourfold increase in particle yields since the 1960s which was thought to be linked to land drainage.

\section{Nature of the lost particles}

Characteristics of the particles lost via the subsurface drainage network are described in studies dealing with either drain clogging (Paterson and Mitchell, 1977; Grass et al., 1979; Süsser and Schwertmann, 1983; Houot and Berthelin, 1992) or with particle sampling at the drainage network outlet. These two kinds of studies gave different pieces of information as the coarser materials settled out first leading to drain clogging, whereas, the finer materials stayed suspended and were transported until the end of the drain. Complete characterizations of the exported particles, combining particle size distribution, chemical and mineralogical compositions, are scarce (Mercier et al., 2000).

Deposits in clogged drains are often laminated, which was interpreted as a formation through a succession of discrete events (Paterson and Mitchell, 1977). These deposits vary considerably in texture ranging from sand to clay (Grass et al., 1979). Interestingly, the washing out of the fine particles accumulated in drainlines over the relatively dry periods, likely participates to the important contribution of storm flow events in annual particle losses. At the drainage outlet, Mercier et al. (2000) measured exported particles finer than $2 \mu \mathrm{m}$ and observed that more than 80\% had a size below $0.45 \mu \mathrm{m}$. Laubel et al. (1999) reported that the median size of the leached particles was smaller than $5 \mu \mathrm{m}$. Coarser particles, however, were transported via subsurface drainage network, but their size never exceeded $50 \mu \mathrm{m}$ (Chapman et al., 2001). 
Combining microscopic observations with chemical analysis and X-ray diffraction, Mercier et al. (2000) found that the transported particles were principally composed of various phyllosilicates and of iron-rich colloids. The identification of iron-rich colloids was consistent with the frequent observation of ochreous deposits rich in Fe in drain lines (Süsser and Schwertmann, 1983; Houot and Berthelin, 1992). These deposits may have been formed in a couple of weeks and are principally composed of ferrihydrite (Süsser and Schwertmann, 1983).

\section{Source of the exported particles}

In order to identify the origin of the exported particles, some of their properties such as particle size distribution, organic carbon, phosphorus or ${ }^{137}$ Cs contents have been compared with those of the soil solid phases (Laubel et al., 1999; Mercier et al., 2000; Chapman et al., 2001; Petersen et al., 2002).

The high contents of phosphorus, organic carbon, ${ }^{137} \mathrm{Cs}$, and the rapid detection in the drainage water of pesticides carried by particles just after their application on the soil surface suggest that particles come from the surface horizon (Laubel et al., 1999; Mercier et al., 2000; Chapman et al., 2001; Petersen et al., 2002). This surface origin is consistent with the similar mineralogy of the exported particles to that of the corresponding particle size fraction of the soil surface horizon (Mercier et al., 2000). However, Schwab et al. (1980) monitored, on the same plot, higher particle losses in deep drains than in shallow drains. In addition, the identification of sandy particles in clogged drains (Grass et al., 1979) suggests that such coarse soil particles would have been filtered through the soil porosity in case of surface origin. Finally, ${ }^{7}$ Be was detected in the exported particles but was absent from the topsoil horizons (Chapman et al., 2001). These two last pieces of evidence suggest in part an origin of the transported particles deeper in the subsoil. Simple mixing models confirmed this double origin of the drain sediments with subsoil contributions occasionally reaching $40 \%$ of the whole export in mass (Chapman et al., 2001, 
2005). Hypothesizing that the particles of subsoil origin could come from the drainage trench, Uusitalo et al. (2001) compared the particle losses for similar soils with drainage trenches backfilled either with topsoil or with wood chips. Particle losses were independent of the backfill material (Uusitalo et al., 2001). To conclude, if one part of the leached soil particles appears to be mobilized at the soil surface by the raindrop impact, the exact origin of the part coming from the subsoil is not completely determined.

Concerning the so-called ochreous deposits, numerous authors hypothesized that they resulted from i) the solubilisation of $\mathrm{Fe}$ and $\mathrm{Mn}$ in the waterlogged horizons overlying the soil layer impeding natural drainage and ii) their transport in dissolved forms towards the drain where they oxidized and precipitated (Grass et al., 1973; Süsser and Schwertmann, 1983; Houot and Berthelin, 1992).

\section{IMPACT OF SUBSURFACE DRAINAGE ON SOIL EVOLUTION}

Soil forming processes affected by subsurface drainage and consequences on soil evolution

Soil evolutions results i) from soil-solution chemical interactions leading to dissolution/precipitation of minerals along the soil profile and element losses through lixiviation; and ii) from physical translocations of soil particles either at the soil surface (erosion) or in the subsurface soil horizons (eluviation/illuviation). These main soil processes are driven by different water fluxes: i) runoff that favors erosion and ii) water flowing through soils that enhances chemical soil/solution interactions and eluviation/illuviation processes. In addition, translocation of soil particles mainly occurs by rapid water flow in macropores, whereas the soil particles are filtered when they reach smaller tortuous pores. In waterlogged soils, chemical soil/solution interactions are mainly function of the duration of the waterlogged period through the redox status of the perched water table. 
As seen previously, subsurface drainage lowers the water table levels, leading to more numerous pores free of water as well as more wetting-drying cycles inducing clay shrinkage and intensive biological activity responsible for higher amounts of macropores. Subsurface drainage consequently leads to higher subsurface water flows at the expense of runoff. Such changes are known to induce a decrease in the intensity of erosion processes as observed for example by Grazhdani et al., (1996) or Turtola and Paajanen (1995) who respectively measured decreases in the average annual particle losses due to erosion by about 35\% after the soil had been drained and by $90 \%$ after the subsurface drainage was renewed.

Alternatively subsurface drainage should enhance the particle mobilization and translocation in subsoil horizons compared to an undrained soil as a result of higher contributions of preferential flows to the total water flows. This theoretical conclusion deduced from the impact of changes in water fluxes on particle mobilization and transport is consistent with qualitative descriptions of clay eluviation pedofeatures in response to subsurface drainage (Kapilevich et al., 1991). Moreover, the change in soil process from erosion to eluviation very likely results in changes in the origin and the nature of the exported particles. The questions of the origin and the nature of the exported particles are however still controversial. Concerning their origin, whilst most studies agreed on a surface origin as main source of the exported particles, the secondary subsoil origin is poorly documented. Given that the amount of exported particles was found to be unaffected by the backfill material of the trench (Uusitalo et al., 2001), we can reasonably hypothesize that at least one part of the exported particles of subsoil origin comes from areas of water fluxes concentrations such as the edge of the trench and/or the horizon just above the soil layer impeding natural drainage in drained soils with the soil layer impeding natural drainage above the drain lines. In case of drain lines above the soil layer impeding natural drainage, the origin of the exported particles is probably more diffuse as the water fluxes are less concentrated. Concerning their nature, only the finest soil particles, notably clay-minerals and iron-rich colloids 
are transported to the end of the drain, whereas, coarser particles are filtered through the soil pores or settled rapidly in the drain lines. Over time, the initial fine particle content of the horizons above the soil layer impeding natural drainage should decrease. Such impact on soil evolution remains, however, impossible to predict due to a lack of quantitative data notably as a function of the soil properties. The only quantitative data was reported by Kapilevich et al., (1991) who measured a nearly $20 \%$ decrease of the initial fine particles in the horizon above the soil layer impeding drainage, showing that this impact of subsurface drainage may be significant.

Concerning chemical soil/solution interactions, the main process driving the hydromorphic soils evolution is the so-called "ferrolysis" (Dreissen et al., 2001; Van Ranst and De Coninck, 2002). This process includes the reduction of Fe from ferric oxides and hydroxides during the "reduction phase" due to a decrease of $\mathrm{pH}$ by the release of $\mathrm{H}^{+}$ions when $\mathrm{Fe}^{2+}$ ions oxidize. By reducing the average duration of the waterlogged period, compared to an undrained soil, subsurface drainage reduces the dissolution of Fe and Mn compounds and consequently the dissolution of clay minerals. However, a water table is still observed in many drained soils. In addition, the formation of Fe and Mn ochreous deposits in drain lines shows that the conditions are, at least temporarily, sufficiently reductive to promote the dissolution of Fe and Mn compounds. To our knowledge, no data can confirm or refute that subsurface drainage sufficiently reduces the average duration of the waterlogged period to completely avoid the dissolution of clay minerals. In addition, when dissolved, the chemicals are partly removed from the soil profile and partly re-precipitated in amorphous phase when the soil dries out. The authors suggest that subsurface drainage favors the removal of the dissolved elements from the soil profile at the expense of precipitation by intercepting the lateral water flows at regular intervals according to the drain spacing. Concerning the impact of drainage on the chemical soil/solution interactions, the authors finally consider that i) the impact of subsurface drainage on the clay mineral dissolution is largely unknown and needs further research to be accurately evaluated; ii) subsurface drainage most probably enhances 
lixiviation, which can lead to significant losses of dissolved elements, notably from the horizon above the soil layer, impeding natural drainage, but Fe and Mn can precipitate in the drain lines; and iii) in most case, redox processes are still active in drained soil as evidences by the formation of ochreous deposits even if the intensity of redox processes decreases. The respective mobility of these two elements due to subsurface drainage is not documented. However, as $\mathrm{Mn}$ is more sensitive than Fe to redox processes (Jenne, 1968), the behavior of Fe should be influenced to a larger extent.

\section{Spatial variability of the drainage impact on soil evolution}

As a result of the initial soil disturbance by subsoiling or trenching and a result of the preferential development of the soil macroporosity in the immediate vicinity of the drain, higher infiltration rates were observed above and close to the drain rather than in the mid-drain positions. Such heterogeneity in the hydraulic properties induced higher water table levels in the mid-drain positions. As observed in the case of distances to a ditch of several tens of meters (Hayes et al., 2000), contrasted redox conditions may be expected, at a ten meter scale, between the mid-drain position (more reductive) and the immediate vicinity of the drain (more oxidative). Moreover, soil drainage favors lateral water fluxes from the mid-drain position to the drainlines. Thus, more water goes through soil in the vicinity of the drainlines than in the mid-drain position.

The authors suggested that these contrasted water fluxes and redox conditions, as a function of the distance to the drain, most probably induced gradients in the intensity of the soil forming processes. Such gradients have, for example, been observed in erosion, whose intensity was higher in the mid-drain position than in the immediate vicinity of the drain (Augeard et al., 2005). On the contrary, the intensity of eluviation and lixiviation probably increased with the amount of water flowing through soil, as the distance to the drain decreased. In addition, the contrasted redox conditions between the mid-drain position and the immediate vicinity of the drain line should give 
rise to specific Fe and Mn behavior: these elements could be mobilized in the mid-drain position, transported with the water flow toward the drain where re-precipitation processes could occur both in the soil itself or in the drain lines, due to more oxidative conditions.

Such gradients in the respective intensity of erosion, eluviation, lixiviation and redox processes, between the mid-drain position and the immediate vicinity of the drain line, should induce a differentiated evolution of the soil solid phase as a function of the distance to the drain and should result in heterogeneities of the soil evolution at a ten meter scale.

\section{Dynamic of soil evolution in response to artificial subsurface drainage}

Following the study of Turtola and Paajanen (1995), demonstrating that particle losses at the drainage network outlet after the subsurface drainage was renewed were considerably higher than before, the authors tried to relate the particle losses reported in Table III to the age of the drainage network in order to clarify the dynamic of soil evolution in response to artificial subsurface drainage. However, no significant relationship was found, probably due to the high spatial and temporal variability of the particle losses, in combination with a lack of particle losses monitoring over time scales of several decades. In addition, as suggested by the impact of storm flow events on the dynamic of particle losses, the authors could conclude that exceptional events may have a spectacular impact on drained soil evolution, as already shown, for example, by Boulaine (1978), for other soil processes.

Nevertheless, the authors can reasonably suggest that first soil evolution in response to subsurface drainage should occur over short-time scales of a few decades. For example, Kapilevich et al. (1991) measured, in the horizon above the hydraulic barrier, a loss of about $20 \%$ of fine particles from the initial content in 18 years, and Hayes et al. (2000) observed significant Fe and Mn redistribution processes in 30 to 50 years. Such rapid soil evolution is consistent with the rapid soil mineral evolutions observed in other pedological contexts. Refait et al. (2001) and Bourrié et 
al. (2004) evidenced ephemeral Fe oxide forms in soils, and Cornu et al. (1995) and Lucas et al. (1996) demonstrated that in tropical soils, kaolinite permanently dissolved and re-precipitated with significant evolutions in time scales as short as six months. Rapid clay transformations on a 20 years scale were also evidenced under other pedological environments (Velde and Church, 1999).

\section{CONCLUSIONS}

Studies have shown not only a reduction in duration of the waterlogged period, but also changes in both the direction and the velocity of water flow in the horizons located above the hydraulic barrier. These results are coherent with observed changes in soil morphology and the measured losses of particles.

From these results the authors can hypothesize that i) subsurface drainage induces a decrease in the intensity of erosion and an increase in the intensity of lixiviation and eluviation, as well as specific redox processes, compared to similar undrained soils, and Fe, Mn, and particle translocations and losses from the soil are of particular concern, ii) these processes do not affect the whole soil to a similar extent due to gradients of water fluxes and waterlogged conditions existing in the immediate vicinity of the drain line to the mid-drain position, and heterogeneities can then be expected at the ten meter scale in the evolution of the horizon above the hydraulic barrier; and iii) soil reacts over time scales of a few decades to the perturbations induced by the subsurface drainage.

A human-induced perturbation of the water fluxes results in changes in the intensity of numerous soil forming processes and finally must induce significant soil evolutions over a time scale that is often neglected in classical pedological studies. Moreover, these recent soil developments such as the loss of the fine soil fraction can no longer be neglected as they are mostly irreversible at a human-life time-scale and probably have unknown, but expected, 
feedbacks on crucial soil properties and functions, such as the ion exchange complex, the sequestration of soil organic matter or the water available capacity.

The authors are however unable at present to quantify the intensity and to accurately describe the dynamic of these recent soil evolutions, due to a lack of quantitative data. To better take into account and model the impact of such human-induced soil evolution on crucial soil functions, a research priority should be the quantification of human-induced soil evolution as a function of time.

\section{ACKNOWLEDGMENTS}

The authors thank Mr. S. Desbourdes, INRA-UR 0272, Orléans, France, for the figure design and Dr. J. Michelin, UMR INRA/AgroParisTech Environnement et Grandes Cultures, Thiverval-Grignon, France, for his help in translating soil names from various soil classifications into the World Reference Base for Soil Resource classification. The authors finally acknowledge the anonymous reviewers for their help in improving the manuscript, and the American Journal Experts Association for English editing.

\section{REFERENCES}

Abbaspour, K.C., Kohler, A., Simunek, J., Fritsch, M. and Schulin, R., 2001. Application of a twodimensional model to simulate flow and transport in a macroporous agricultural soil with tile drains. European Journal of Soil Science, 52: 433-447.

Augeard, B., Kao, C., Chaumont, C. and Vauclin, M., 2005. Mechanisms of surface runoff genesis on a subsurface drained soil affected by surface crusting: a field investigation. Physics and chemistry of the earth, 30: 568-610.

Belamie, R. and Vollat, B., 1986. Etude de la qualité des eaux de drainage. Périmètre expérimental d'Arrou (Eure et Loir). Etudes du Cemagref: Hydraulique Agricole, 1: 5-44. 
Bengtson, R.L., Carter, C.E., Fouss, J.L., Southwick, L.M. and Willis, G.H., 1995. Agricultural drainage and water quality in Mississippi delta. Journal of Irrigation and Drainage Engineering, 121(4): 292-295.

Bengtsson, L., Seun, P., Lepistö, A. and Saxena, R.K., 1992. Particle movement of melt water in a subdrained agricultural basin. Journal of Hydrology, 135: 383-398.

Bottcher, A.B., Monke, E.J. and Huggins, L.F., 1980. Subsurface drainage and sediment transport model. Transactions of the ASAE, 23(4): 870-876.

Bottcher, A.B., Monke, E.J. and Huggins, L.F., 1981. Nutrient and sediment loadings from a subsurface drainage system. Transactions of the ASAE, 24(5): 1221-1226.

Boulaine, J. 1978. Les sols Calfersiques. Cah. ORSTOM, série Pédologie (in French), 16: 265-291.

Bourrié, G., Trolard, F., Refait, P. and Feder, F., 2004. A solid-solution model for Fe(II)-Fe(III)$\mathrm{Mg}(\mathrm{II})$ green rusts and fougerite and estimation of their Gibbs free energies of formation. Clays and Clay Minerals, 52: 382-394.

Carter, A., Heinonen, J. and Vries, J.d., 1982. Earthworms and water movement. Pedobiologia, 23(6): 395-397.

Chadwick, O.A. and Chorover, J., 2001. The chemistry of pedogenic tresholds. Geoderma, 100: 321-353.

Chapman, A.S., Foster, I.D.L., Lees, J.A. and Hodgkinson, R.A., 2005. Sediment delivery from agricultural land to rivers via subsurface drainage. Hydrol. Process., 19: 2875-2897.

Chapman, A.S., Foster, I.D.L., Lees, J.A., Hodgkinson, R.A. and Jackson, R.H., 2001. Particulate phosphorus transport by sub-surface drainage from agricultural land in the UK. Environmental significance at the catchment and national scale. The Science of the Total Environment, 266: 95-102. 
Cornu, S., Lucas, Y., Desjardins, T. and Nietsch, S., 1995. Mise en évidence des vitesses d'altération des minéraux du sol en conditions ferrallitiques. Méthode des minéraux tests. Compte Rendu de l'Académie des Sciences Paris, série IIa (in French), 312: 311-316.

Cros, P. and Jacquin, F., 1972. Expérimentation de l'Ecole nationale supérieure agronomique de Nancy et du Centre technique du Génie rural des Eaux et Forêts. Bulletin technique d'information - Ministère de l'agriculture, 273-274: 947-953.

Djodjic, F., Ulén, B. and Bergström, L., 2000. Temporal and spatial variations of phosphorous losses and drainage in a structured clay soil. Wat. Res., 34(5): 1687-1695.

Dreissen, P., Deckers, J., Spaargaren, O. and Nachtergaele, F. (Editors), 2001. Lectures Notes on the Major Soils of the World. World soil resources reports No 94. FAO, Rome, 344 pp.

Foster, I.D.L., Chapman, A.S., Hodgkinson, R.M., Jones, A.R., Lees, J.A., Turner, S.E. and Scott, M., 2003. Changing suspended sediment and particulate phosphorus loads and pathways in underdrained lowland agricultural catchments, Herefordshire and Worcestershire, U.K. Hydrobiologia, 494: 119-126.

Gardner, W.K., Drendel, M.F. and McDonald, G.K., 1994. Effects of subsurface drainage, cultivation, and stubble retention on soil porosity and crop growth in a high rainfall area. Aust. J. Exp. Agr., 34: 411-418.

Gish, T.J., Kung, K.J.S., Perry, D.C., Posner, P., Bubenzer, G., Helling, C.S., Kladivsko, E.F. and Steenhuis, T.S., 2004. Impact of preferential flow at varying irrigation rates by quantifying mass fluxes. J. Environ. Qual., 33: 1033-1040.

Grant, R. et al., 1996. Loss of dissolved and particulate phosphorus from arable catchment by subsurface drainage. Wat. Res., 30(11): 2633-2644.

Grass, L.B., Mackenzie, A.J., Meek, B.D. and Spencer, W.F., 1973. Manganese and iron solubility changes as a factor of tile drain clogging: I. Observation during flooding and drying. Soil Sci. Soc. Amer. Proc., 37: 14-17. 
Grass, L.B., Willardson, L.S. and LeMert, R.A., 1979. Soil sediment deposits in subsurface drain. Transactions of the ASAE, 22(5): 1054-1057.

Grazhdani, S., Jacquin, F. and Sulçe, S., 1996. Effect of subsurface drainage on nutrient pollution of surface waters in south eastern Albania. The Science of the Total Environment, 191: 1521.

Hayes, W.A., Vepraskas, J. and Vepraskas, M.J., 2000. Morphological changes in soils produced when hydrology is altered by ditching. Soil Sci. Soc. Am. J., 64: 1893-1904.

Houot, S. and Berthelin, J., 1992. Submicroscopic studies of iron deposits occurring in field drains: formation and evolution. Geoderma, 52(3-4): 209-222.

Husnjak, S., Bogunovic, M. and Simunic, I., 2002. Soil moisture regime of ameliorated Gleyic Stagnosol. Agriculturae Conspectus Scientificus, 67(4): 169-179.

IUSS Working Group WRB. 2006. World Reference Base for Soil Resources 2006. World Soil Resources Reports No. 103. FAO, Rome.

Jenne, E.A., 1968. Controls on $\mathrm{Mn}, \mathrm{Fe}, \mathrm{Co}, \mathrm{Ni}, \mathrm{Cu}$ and $\mathrm{Zn}$ concentrations in soils and waters: the significant role of hydrous Mn and Fe oxides. In: R.F. Gould (Editor), Trace inorganics in water. American Chemical Society, Washington DC, pp. 337-387.

Jenny, H., 1941. Factors of soil formation: a system of quantitative pedology. McGraw-Hill, NewYork, USA.

Jenny, H., 1961. Derivation of state factor equations of soils and ecosystems. Soil Sci. Soc. Am. J., 25: 385-388.

Kapilevich, Z.A., Tselishcheva, L.K. and Vysochenko, A.V., 1991. Transformation of soils developing on glacial-lacustrine clays after drainage. Soviet Soil Science, 23(8): 9-18.

Kladivko, E.J., Scoyoc, G.E.v., Monke, E.J., Oates, K.M. and Pask, W., 1991. Pesticides and nutrient movement into subsurface tile drains on a silt loam soil in Indiana. Journal of Environmental Quality, 20: 264-270. 
Kohler, A., Abbaspour, K.C., Fritsch, M. and Schulin, R., 2003. Using simple bucket models to analyze solute export to suvusrface drains by preferential flow. Vadose Zone Journal, 2: 6875.

Köhne, J.M. and Gerke, H.H., 2005. Spatial and temporal dynamics of preferential bromide movement towards a tile drain. Vadose Zone Journal, 4(79-85).

Koskiaho, J. et al., 2002. Reduced Tillage: Influence on erosion and nutrient losses in a clayley field in southern Finland. Agricultural and Food Science in Finland, 11: 37-50.

Kronvang, B., Laubel, A. and Grant, R., 1997. Suspended sediment and particulate phophorus transport and delivery pathways in an arable catchment, Gelbaek stream, Denmark. Hydrological Processes, 11: 627-642.

Kumar, A., Kanwar, R.S. and Hallberg, G.R., 1997. Separating preferential and matrix flows using subsurface tile flow data. Journal of Environmental Science and Health Part A Environmental Science and Engineering \& toxic and hazardous substance control, 32(6): 1711-1729.

Kung, K.J.S. et al., 2000. Quantifying preferential breakthrough of sequentially applied tracers: silt loam soil. Soil Sci. Soc. Am. J., 64: 1296-1304.

Kung, K.J.S. et al., 2000. Impact of preferential flow on the transport of adsorbing and nonadsorbing tracers. Soil Sci. Soc. Am. J., 64: 1290-1296.

Laubel, A., Jacobsen, O.H., Kronvang, B., Grant, R. and Andersen, H.E., 1999. Subsurface drainage loss of particles and phosphorus from field plot experiments and a tile-drained catchment. J. Environ. Qual., 28: 576-584.

Lennartz, B., Michaelsen, J., Wichtmann, W. and Widmoser, P., 1999. Time variance analysis of preferential solute movement at a tile-drained field site. Soil Sci. Soc. Am. J., 3: 39-47.

Lesaffre, B. and Zimmer, D., 1987. Modélisation du comportement hydraulique d'un sol drainé débits de pointe et tarissements. Science du Sol, 25(4): 231-246. 
Lesaffre, B. and Zimmer, D., 1987. Régime hydrique d'un sol drainé: Comparaison des phases débit de pointe et tarissement. Science du Sol, 25(4): 217-229.

Lin, H., Bouma, J., Wilding, L.P., Richardson, J.L., Kutilek, M. and Nielsen, D.R., 2005. Advances in Hydropedology. Advances in Agronomy, 85: 1-89.

Lucas, Y., Nahon, D., Cornu, S. and Eyrolle, F., 1996. Soil genesis and dynamics in equatorial areas. C. R. Acad. Sci. Paris, série IIa (in French), 322: 1-16.

Mercier, P., Denaix, L., Robert, M. and de Marsily, G., 2000. Colloid transfer by subsurface drainage. C. R. Acad. Sci. Paris, série IIa (in French), 331: 195-202.

Mercier, P. 1998. Contribution méthodologique à l'étude des matières en suspension. Application au transfert particulaire en sol drainé (in French). Ph. D. Dissertation, ENGREF Paris, France.

Mériaux, S., 1973. Sur le processus de fonctionnement des drains en sol lessivé hydromorphe. Ann. agron., 24(6): 639-650.

Mériaux, S., Perrey, C. and Lavielle, G., 1971. Premières données sur la dynamique comparée de l'eau dans deux systèmes d'assainissement en sol lessivé hydromorphe. C.R. Acad. Agric. Fr.: 146-166.

Merot, P. and Hamdi, H., 1991. Traçage de l'eau d'une parcelle argileuse drainée. Hydraulique Agricole, 10: 89-105.

Novak, S.M., Banton, O. and Schiavon, M., 2003. Modelling metalochlor exports in subsurface drainage water from two structured soils under maize (eastern France). Journal of Hydrology, 270: 295-308.

Øygarden, L., Kvaerner, J. and Jenssen, P.D., 1997. Soil erosion via preferential flow to drainage system in clay soils. Geoderma, 76: 65-86.

Paterson, E. and Mitchell, B.D., 1977. Erosion deposits in tile-drains. Agricultural Water Management, 1(4): 311-317. 
Penven, M.J. and Muxart, T., 1995. Le drainage agricole: un rôle fondamental dans les transferts d'eau et de matière. L'exemple du plateau briard. Ann. Géo., 581-582: 88-104.

Penven, M.J. et al., 1998. Chapitre 4: Petits bassins ruraux et pollutions diffuses. In: M. M., D.M. G. and F. E. (Editors), La Seine en son bassin: Fonctionnement écologique d'un système fluvial anthropisé. Elsevier, Paris, pp. 159-210.

Petersen, C.T., Hansen, S., Jensen, H.E., Holm, J. and Bender Koch, C., 2004. Movement of suspended matter and a bromide tracer to field drains in tilled and untilled soil. Soil Use and Management, 20: 271-280.

Petersen, C.T., Holm, J., Koch, C.B., Jensen, H.E. and Hansen, H.C.B., 2002. Movement of pendimethalin, ioxynil and soil particles to field drainage tiles. Pest. Manag. Sci., 59: 8596.

Refait, P., Abdelmoula, M., Trolard, F., Genin, J.M.R., Ehrardt, J.J. and Bourrié, G., 2001. Mossbauer and XAS study of a green rust mineral; the partial substitution of $\mathrm{Fe}^{2+}$ by $\mathrm{Mg}^{2+}$. Am. Mineral., 86: 731-736.

Russel, M.A., Walling, D.E. and Hodgkinson, R.A., 2001. Suspended sediment sources in two small lowland agricultural catchments in the UK. J. Hydrol., 252: 1-24.

Schwab, G.O., Fausey, N.R. and Kopcak, D.E., 1980. Sediment and Chemical content of agricultural drainage water. Transactions of the ASAE, 23(6): 1446-1449.

Shipitalo, M.J., Nuutinen, V. and Butt, K.R., 2004. Interaction of earthworm burrows and cracks in a clayley, subsurface-drained, soil. Applied Soil Ecology, 26: 209-217.

Simard, R.R., Beauchemin, S. and Haygarth, P.M., 2000. Potential for preferential pathways of phosphorous transport. J. Environ. Qual., 29: 97-105.

Skaggs, R.W., Breve, M.A. and Gilliam, J.W., 1994. Hydrologic and water quality impact of agricultural drainage. Critical Reviews in Environmental Science and Technology, 24(1): 132. 
Sogon, S., Penven, M.J., Bonté, P. and Muxart, T., 1999. Estimation of sediment yield and soil loss using suspended sediment load and ${ }^{137}$ Cs measurements on agricultural land, Brie Plateau, France. Hydrobiologia, 410: 251-261.

Stamm et al., 2002. Multiple tracing of fast solute transport in a grassland soil. Geoderma, 109(34): $245-268$.

Süsser, P. and Schwertmann, U., 1983. Iron oxide mineralogy of ochreous deposits in drain pipes and ditches. Z. f. Kulturtechnik und Flurbereinigung, 24: 386-395.

Trouche, G., 1981. Aspects agronomiques et hydrodynamiques du drainage des sols à profil différencié du val de Saône, Institut des Sciences de la Terre de l'université de Dijon, Dijon, $201 \mathrm{pp}$.

Turtola, E. and Paajanen, A., 1995. Influence of improved subsurface drainage on phosphorus losses and nitrogen leaching from a heavy clay soil. Agricultural water management, 28: 295-310.

Ulen, B. and Persson, K., 1999. Field-scale phosphorus losses from a drained clay soil in Sweden. Hydrol. Processes, 13(17): 2801-2812.

Urbanek, J. and Dolezal, F., 1992. Review of some case studies on the abundance and the hydraulic efficiency of eartworm channels in Czechoslovak soils, with reference to the subsurface pipe drainage. Soil Biol. Biochem., 12: 1563-1571.

Uusitalo, R., Turtola, E., Kauppila, T. and Lilja, T., 2001. Particulate phosphorus and sediment in surface runoff and drainflow from clayey soil. J. Environ. Qual., 30(2): 589-595.

Van Ranst, E. and De Coninck, F., 2002. Evaluation of ferrolysis in soil formation. European Journal of Soil Science, 53: 513-519.

Velde, B. and Church, T., 1999. Rapid clay transformation in Delaware salt marsh. Appl. Geochem., 14: 559-568. 
Villholth, K.G., Jarvis, N.J., Jacobsen, O.H. and de Jonge, H., 2000. Field investigations and modeling of particle-facilitated pesticide transport in macroporous soil. J. Environ. Qual., 29: 1298-1309.

Walling, D.E. Russel, M.A., Hodgkinson, R.A. and Zhang, Y., 2002. Establishing sediment budgets for two small lowland agricultural catchments in the UK. Catena, 47: 323-353.

Yaalon, D.H. and Yaron, B., 1966. Framework for man-made soil changes: an outline of metapedogenesis. Soil Science, 102(4): 272-277.

Zaidel'man, F.R. and Vashkova, S.I., 1989. Influence of gleization, drainage, and subsoiling on structural status of Gleyed soils on varve clays. Pochvovedenie (in Russian), 44: 45-50.

Zehe, E. and Flühler, H., 2001. Preferential transport of isoproturon at a plot scale and a field scale tile-drained site. Journal of Hydrology, 247: 100-115. 
1 Fig. 1: Schematic representation of the surface and subsurface water flows in a drained soil with drain lines (a) above and (b) below the soil layer, impeding natural drainage.
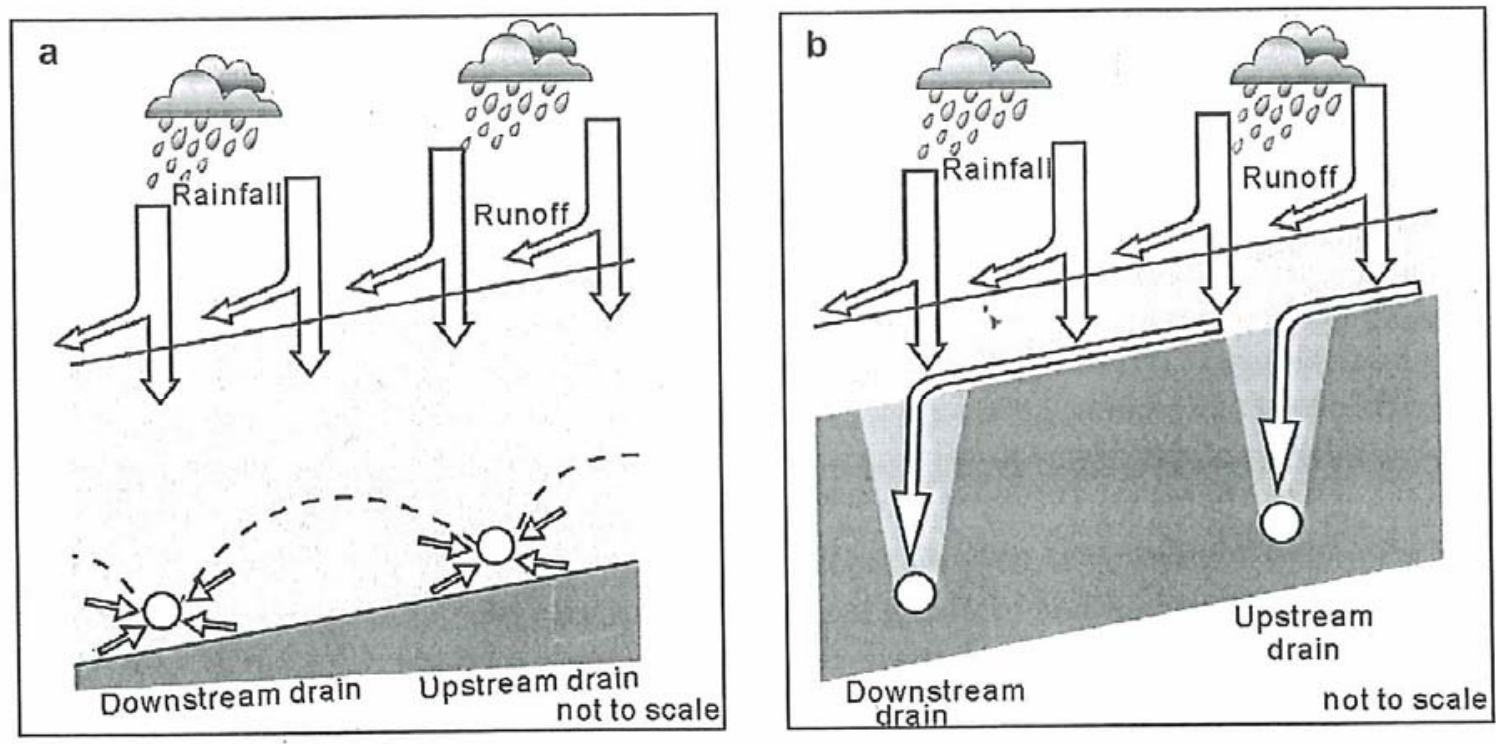

Permeable soil Disturbed material 
TABLE I

5 Infiltration and bulk density above the drain lines and in the mid-drain position

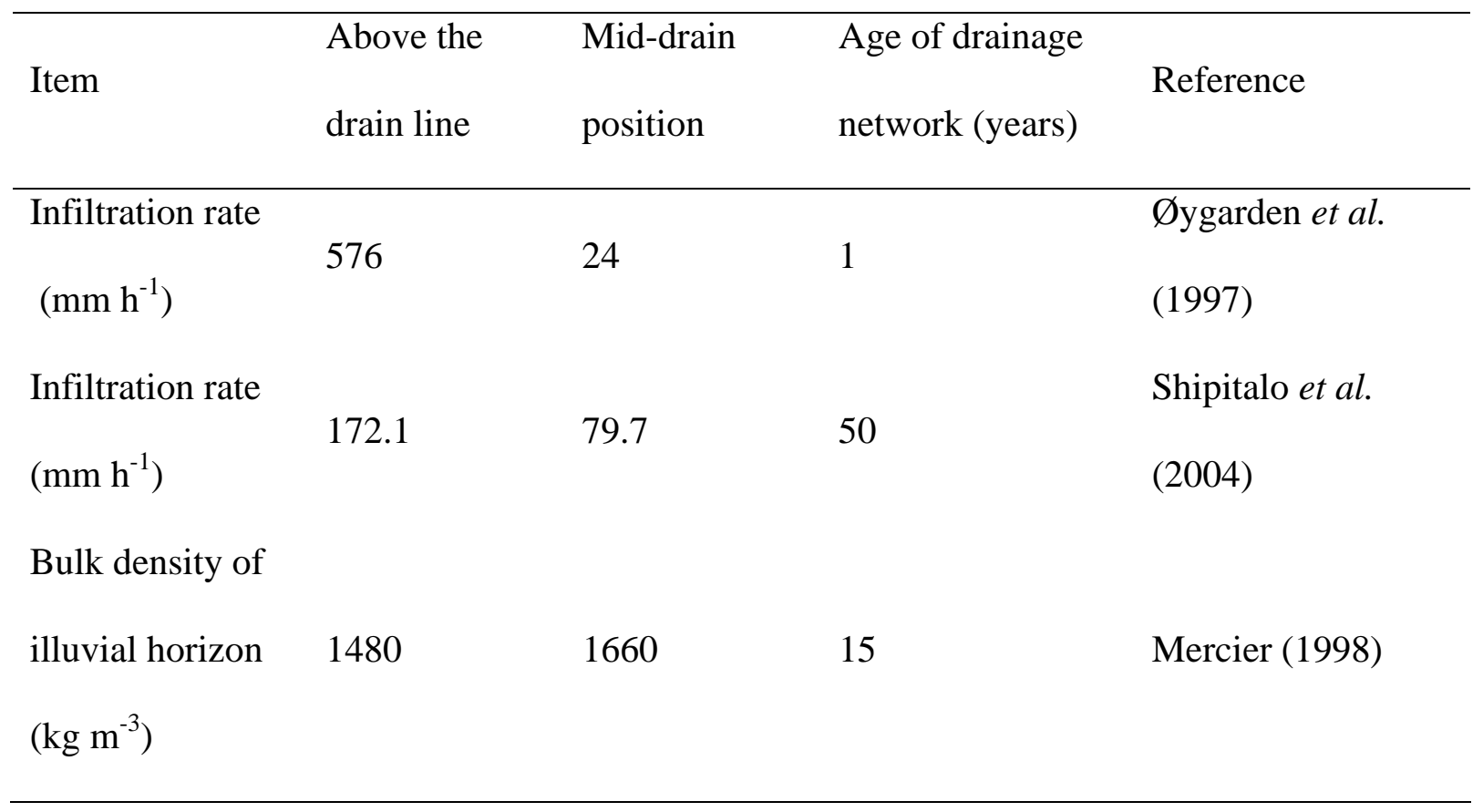




\section{TABLE II}

8 Main soil characteristics and associated subsurface drainage types encountered in the references

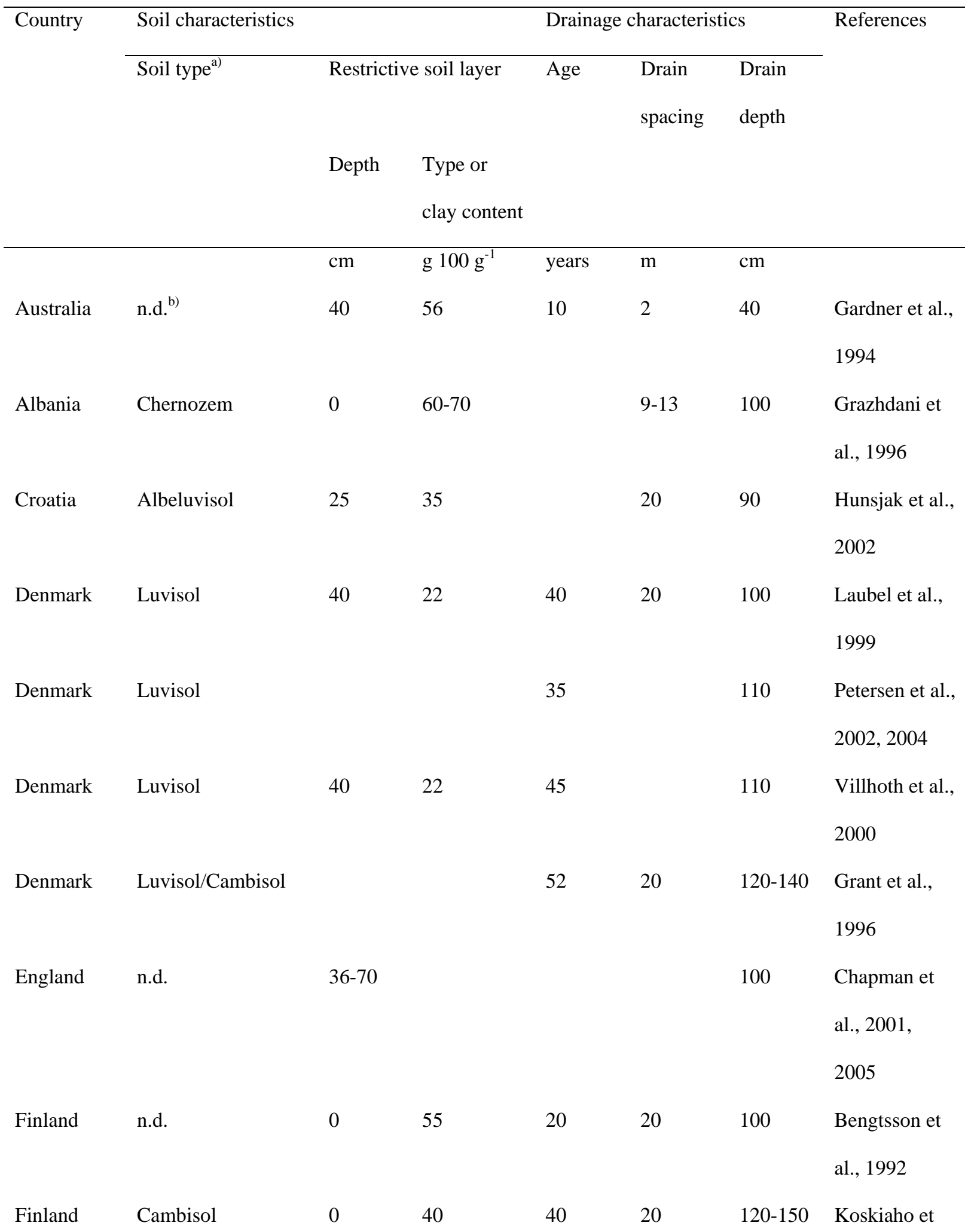




\begin{tabular}{|c|c|c|c|c|c|c|c|}
\hline & & & & & & & al., 2002 \\
\hline Finland & Cambisol & 0 & 60 & 50 & 16 & 100 & $\begin{array}{l}\text { Shipitalo et } \\
\text { al., } 2004\end{array}$ \\
\hline Finland & Cambisol & 0 & 60 & 30 & 16.5 & 100 & $\begin{array}{l}\text { Turtola and } \\
\text { Paajanen, } \\
1995\end{array}$ \\
\hline Finland & Cambisol/Cambisol & 0/n.d. & 60/n.d. & $30 / 50$ & 16.5/n.d. & $100 / 100$ & $\begin{array}{l}\text { Uusitalo et al., } \\
2001\end{array}$ \\
\hline France & Albeluvisol & $25-50$ & n.d. & $>40$ & 10 & $50-70$ & $\begin{array}{l}\text { Augeard et al., } \\
2005\end{array}$ \\
\hline France & Albeluvisol/Vertisol & $60 / 0$ & $35 / 50$ & $3 / 3$ & $12 / 8$ & 90 & $\begin{array}{l}\text { Cros and } \\
\text { Jacquin, } 1972\end{array}$ \\
\hline France & n.d. & 45 & 25 & 5 & 12 & 100 & Trouche, 1981 \\
\hline France & Luvisol & 26 & 31 & 15 & n.d. & $60-80$ & $\begin{array}{l}\text { Sogon et al., } \\
1999\end{array}$ \\
\hline France & Luvisol & 26 & 31 & 15 & n.d. & $60-80$ & $\begin{array}{l}\text { Mercier, } \\
\text { 1998; Mercier } \\
\text { et al., } 2000\end{array}$ \\
\hline France & Luvisol & 50 & 40 & 5 & 10 & 70 & $\begin{array}{l}\text { Mériaux et al., } \\
\text { 1971; } \\
\text { Mériaux, } 1973\end{array}$ \\
\hline France & Luvisol/Cambisol & $40 / 0$ & $37 / 54$ & 34 & $12 / 8$ & 90 & $\begin{array}{l}\text { Novak et al., } \\
2003\end{array}$ \\
\hline France & Vertic Cambisol & 0 & n.d. & 8 & 10 & 85 & $\begin{array}{l}\text { Merot and } \\
\text { Hamdi, } 1991\end{array}$ \\
\hline Germany & Gleysol & $30-40$ & Plow pan & n.d. & $11-15$ & 100 & $\begin{array}{l}\text { Köhne and } \\
\text { Gerke, } 2005\end{array}$ \\
\hline Germany & Gleysol & $30-40$ & Plow pan & n.d. & $11-15$ & 100 & $\begin{array}{l}\text { Lennartz et } \\
\text { al., } 1999\end{array}$ \\
\hline Germany & Luvisol & n.d. & n.d. & n.d. & n.d. & n.d. & Zehe and \\
\hline
\end{tabular}


Flühler, 2001

\begin{tabular}{|c|c|c|c|c|c|c|c|}
\hline Norway & n.d. & 20 & 35 & 10 & 4 & $70-90$ & $\begin{array}{l}\text { Øygarden et } \\
\text { al., } 1997\end{array}$ \\
\hline Russia & Albeluvisol/Gleysol & $40-45$ & n.d. & 10 & 10 & 100 & $\begin{array}{l}\text { Kapilevilevich } \\
\text { et al., } 1991\end{array}$ \\
\hline Russia & Albeluvisol/Gleysol & 28/n.d. & $\begin{array}{l}17.4 \\
(<1 \mu \mathrm{m}) / \text { n.d. }\end{array}$ & 10 & 10 & n.d. & $\begin{array}{l}\text { Zaidel'man } \\
\text { and } \\
\text { Vashkova, } \\
1989\end{array}$ \\
\hline Scotland & Cambisol/Gleysol & n.d. & $44 / 37$ & $>60$ & 3 & 100 & $\begin{array}{l}\text { Paterson and } \\
\text { Mitchell, } 1977\end{array}$ \\
\hline Sweden & Cambisol & 0 & 59 & 60 & Irregular & $100-120$ & $\begin{array}{l}\text { Ulen and } \\
\text { Persson, } 1999\end{array}$ \\
\hline Sweden & Phaeozem & 0 & 46.5 & 65 & 3.5 & 100 & $\begin{array}{l}\text { Djodjic et al., } \\
2000\end{array}$ \\
\hline Switzerland & Cambisol & 10 & 28 & $>50$ & 10 & $100-150$ & $\begin{array}{l}\text { Stamm et al., } \\
2002\end{array}$ \\
\hline Switzerland & Gleysol & n.d. & n.d. & & 20 & 100 & $\begin{array}{l}\text { Abbaspour et } \\
\text { al., } 2001\end{array}$ \\
\hline Switzerland & Gleysol & n.d. & n.d. & $>80$ & 20 & 100 & $\begin{array}{l}\text { Kohler et al., } \\
2003\end{array}$ \\
\hline USA & n.d. & n.d. & n.d. & n.d. & n.d. & 180 & $\begin{array}{l}\text { Grass et al., } \\
\text { 1973, } 1979\end{array}$ \\
\hline USA & n.d. & n.d. & n.d. & n.d. & 36 & 120 & $\begin{array}{l}\text { Kumar et al., } \\
1997\end{array}$ \\
\hline USA & Albeluvisol & 120 & n.d. & 8 & $5,10,20$ & 75 & $\begin{array}{l}\text { Kladivko et } \\
\text { al., } 1991\end{array}$ \\
\hline USA & Albeluvisol & n.d. & n.d. & 20 & n.d. & n.d. & $\begin{array}{l}\text { Kung et al., } \\
\text { 2000a }\end{array}$ \\
\hline USA & Gleyic Cambisol & 0 & 50 & 22 & 12 & 100 & Schwab et al., \\
\hline
\end{tabular}


USA

Gleyic Fluvisol

n.d. n.d.

n.d. $\quad 10$ or $20 \quad 100$

Bengston et

USA

Gleyic Luvisol

n.d.

n.d.

25

20

100-200 Bottcher et al.,

USA

Gleyic Luvisol

40

Clayey hard 15

n.d.

90

1980, 1981

USA

Phaeozem

35

pan

n.d.

34

18

90-110

Gish et al.,

2004

10

a)Soils are named according to the World Reference Base (WRB) Classifications (IUSS

11 Working Group WRB, 2006)

12 b)No data or data not precise enough in the cited reference. 


\section{TABLE III}

14 Published soil losses through subsurface drainage networks in drained cultivated soils

\begin{tabular}{|c|c|c|c|c|c|c|}
\hline \multirow[t]{2}{*}{ Soil type $^{a}$} & \multirow{2}{*}{$\begin{array}{l}\text { Period of } \\
\text { study }\end{array}$} & \multicolumn{2}{|c|}{ Drainage water } & \multicolumn{2}{|c|}{ Surface runoff } & \multirow[t]{2}{*}{ Reference } \\
\hline & & Drain flow & Soil losses & Runoff & Soil losses & \\
\hline & & $\mathrm{mm}_{\text {year }}{ }^{-1}$ & $\mathrm{~kg} \mathrm{ha}^{-1}$ year $^{-1}$ & mm year $^{-1}$ & $\begin{array}{l}\text { kg ha }^{-1} \\
\text { year }^{-1}\end{array}$ & \\
\hline n.d. ${ }^{\text {b) }}$ & 1987-1992 & $54-404$ & $120-3010$ & 88-292 & $200-2630$ & $\begin{array}{l}\text { Øygarden et al., } \\
1997\end{array}$ \\
\hline Cambisol & 1986-1995 & $74-105$ & $158-324$ & $91-114$ & $160-479$ & $\begin{array}{l}\text { Koskiaho et al., } \\
2002\end{array}$ \\
\hline Cambisol & 1987-1993 & $32-309$ & $110-1302$ & n.d. & n.d. & $\begin{array}{l}\text { Turtola and } \\
\text { Paajanen, } 1995\end{array}$ \\
\hline Cambisol & 1992-1998 & $38-326$ & $25-221$ & n.d. & n.d. & $\begin{array}{l}\text { Ulen and } \\
\text { Persson, } 1999\end{array}$ \\
\hline Chernozem & 1992-1995 & $130-169$ & 203-215 & $172-253$ & $\begin{array}{l}1752- \\
2992\end{array}$ & $\begin{array}{l}\text { Grazdhani et al., } \\
1996\end{array}$ \\
\hline Gleyic & 1969-1978 & $29-354$ & $82-5405$ & $46-331$ & $221-9054$ & Schwab et al., \\
\hline Cambisol & & & & & & 1980 \\
\hline Gleyic & $1976-1978$ & n.d. & $21-140$ & n.d. & n.d. & Bottcher et al., \\
\hline Luvisol & & & & & & 1981 \\
\hline Luvisol & 1991-1995 & $41-352$ & $1-240$ & n.d. & n.d. & $\begin{array}{l}\text { Sogon et al., } \\
1998\end{array}$ \\
\hline Luvisol & 1994-1995 & $3.7-23.4$ & $0.9-11.3$ & n.d. & n.d. & $\begin{array}{l}\text { Laubel et al., } \\
1999\end{array}$ \\
\hline Luvisol & 1998-2002 & $2.9-44$ & $0.09-4.3$ & n.d. & n.d. & $\begin{array}{l}\text { Petersen et al., } \\
2004\end{array}$ \\
\hline Phaeozem & 1993-1997 & $100-480$ & $20-200$ & n.d. & n.d. & $\begin{array}{l}\text { Djodjic et al., } \\
2000\end{array}$ \\
\hline
\end{tabular}


15 a)Soils are named according to the World Reference Base (WRB) Classifications (IUSS Working Group WRB, 2006)

b)No data or data not precise enough in the cited reference.

18 